Jurnal Sistem Informasi (Journal of Information Systems). 2/13 (2017), 90-96

DOI: http://dx.doi.org/10.21609/jsi.v13i2.544

\title{
ANALISIS KESUKSESAN IMPLEMENTASI REKAM MEDIS ELEKTRONIK DI RS UNIVERSITAS GADJAH MADA
}

\author{
Rika Andriani ${ }^{1}$, Hari Kusnanto ${ }^{2}$, Wahyudi Istiono ${ }^{3}$ \\ ${ }^{1}$ Minat SIMKES Prodi Ilmu Kesehatan Masyarakat, Fakultas Kedokteran, UGM, Yogyakarta \\ ${ }^{2}$ Prodi Ilmu Kesehatan Masyarakat, Fakultas Kedokteran, UGM, Yogyakarta \\ ${ }^{3}$ Dept. Kedokteran Keluarga \& Kedokteran Komunitas, Fakultas Kedokteran, UGM, Yogyakarta \\ Email: rika.andriani@mail.ugm.ac.id
}

\begin{abstract}
Electronic Medical Record (EMR) is a computerized health information system that contains demographic and medical data, and some of them equipped with decision support system. EMR make health services management better. RS Universitas Gadjah Mada is one of health care providers using EMR. EMR is a mandatory application in RS Universitas Gadjah Mada. EMR development need to fit the needs and expectations of users. MMUST is a model for assessing success implementation IT in mandatory environment. Users are the succes key an information system. By understanding user's perception, it can be known the obstacles to maximize adoption of EMR in improving service quality. The study aims to analyze the successful implementation of EMR based MMUST. The research type is quantitative with cross sectional design. Data from 100 users selected by simple random sampling were analyzed by SEM-PLS analysis technique using SmartPLS 3.2.3 software. The result of this study proved that all MMUST variables have an effect on the success of RME implementation with $R^{2}$ of information satisfaction 0.394; performance expectations 0.292 ; overall satisfaction 0.602 ; net benefit 0.444 ; and attitude 0.655 . Value of Goodness of Fit (GoF) was 0.5777 , so this model was substantially enough to represent the research result.
\end{abstract}

Keywords: electronic medical record, mandatory, model for mandatory use of software technologies

\begin{abstract}
Abstrak
Rekam Medis Elektronik (RME) merupakan sistem informasi kesehatan terkomputerisasi yang berisi data sosial dan data medis pasien, serta dapat dilengkapi dengan sistem pendukung keputusan. RME dapat membantu manajemen pelayanan kesehatan pasien dengan lebih baik. RS Universitas Gadjah Mada mewajibkan penggunaan RME. Saat ini RME dalam tahap pengembangan. Pengguna merupakan aspek penting untuk mewujudkan RME yang ideal. MMUST merupakan model untuk menilai kesuksesan sistem pada lingkungan mandatory. Dengan memahami persepsi pengguna mengenai RME dapat ditemukan rekomendasi yang tepat untuk memaksimalkan adopsi RME untuk meningkatkan kualitas pelayanan pasien. Penelitian ini menganalisis faktor-faktor penentu kesuksesan implementasi RME di RS Universitas Gadjah Mada berdasarkan MMUST. Jenis penelitian adalah penelitian kuantitatif dengan rancangan cross sectional. Data dari 100 pengguna RME yang dipilih secara simple random sampling dianalisis dengan teknik analisis SEM-PLS menggunakan software SmartPLS 3.2.3. Hasi penelitian ini membuktikan seluruh variabel MMUST berpengaruh terhadap kesuksesan implementasi RME dengan nilai $R^{2}$ kepuasan informasi 0,394; harapan kinerja 0,292; kepuasan keseluruhan 0,602; manfaat keseluruhan 0,444; dan sikap 0,655. Nilai Goodness of Fit (GoF) sebesar 0.5777, sehingga dapat disimpulkan model penelitian ini secara substansial merepresentasikan hasil penelitian.
\end{abstract}

Kata kunci: rekam medis elektronik, mandatory, model for mandatory use of software technologies

\section{Pendahuluan}

Salah satu pelayanan di fasilitas pelayanan kesehatan yang dapat diintegrasikan dengan teknologi informasi adalah rekam medis. Rekam medis elektronik (RME) merupakan suatu sistem informasi kesehatan terkomputerisasi yang berisi data demografi, data medis, dan dapat dilengkapi dengan sistem pendukung keputusan. Fasilitas pelayanan keseha- tan mengimplementasikan RME sebagai upaya untuk meningkatkan kualitas pelayanan, meningkatkan kepuasan pasien, meningkatkan akurasi pendokumentasian, mengurangi clinical errors, dan mempercepat akses data pasien [1].

RS Universitas Gadjah Mada merupakan salah satu institusi penyedia layanan kesehatan yang menggunakan RME. RME merupakan aplikasi yang diwajibkan di RS Universitas Gadjah Mada. 


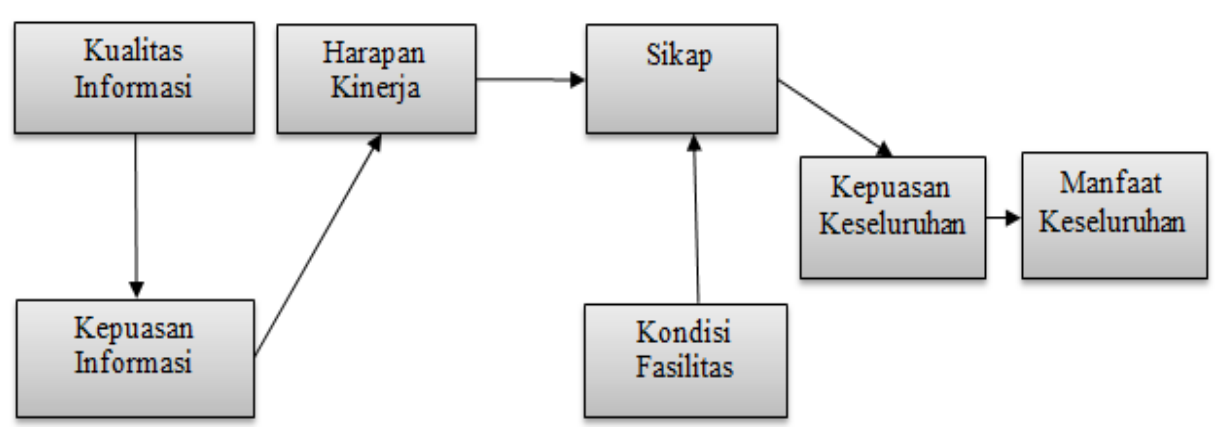

Gambar 1. Model Penelitian

RME digunakan untuk mencatat data demografi, riwayat penyakit, pengobatan, tindakan, hingga pembayaran pada bagian pendaftaran, poliklinik, bangsal rawat inap, unit penunjang, dan kasir. Saat ini, RME masih dalam tahap pengembangan agar sesuai dengan kebutuhan dan harapan pengguna. Pengguna merupakan aspek penting untuk mewujudkan RME yang ideal [2], [3]. Pengguna merupakan kunci utama berhasil atau tidaknya suatu sistem informasi. Dengan memahami persepsi pengguna maka dapat diketahui rekomendasi yang tepat untuk memaksimalkan adopsi RME dalam meningkatkan kualitas pelayanan pasien.

Penelitian mengenai kesuksesan suatu sistem informasi sudah banyak dilakukan. Namun hanya beberapa penelitian yang membedakan sifat penggunaan sistem, apakah bersifat wajib (mandatory) atau sukarela (voluntary). Model for Mandatory Use of Software Technologies (MMUST) merupakan suatu model yang digunakan untuk menilai kesuksesan suatu sistem informasi yang bersifat mandatory [4]. MMUST merupakan penggabungan dari beberapa model sistem informasi, yaitu UTAUT [5], Model DeLone \& McLean [6], dan Model Wixom \& Todd [7].

Dalam penelitian ini MMUST dipilih untuk menganalisis kesuksesan implementasi RME karena RME merupakan aplikasi yang bersifat mandatory di RS Universitas Gadjah Mada. Penelitian ini menganalisis variabel-variabel MMUST yang berpengaruh terhadap kesuksesan implementasi RME di RS Universitas Gadjah Mada.

\section{Metode}

Penelitian ini merupakan penelitian kuantitatif, dengan desain penelitian cross sectional. Jumlah sampel sebanyak 100 responden yang terpilih melalui simple random sampling. Responden terdiri dari petugas rekam medis, dokter, perawat, dan staf unit penunjang (Tabel 1). Penelitian ini menggunakan instrumen berupa kuesioner tertutup dengan skala Likert untuk pengumpulan data.
Penelitian ini dikembangkan dari MMUST. Penelitian ini melakukan beberapa modifikasi yaitu penambahan variabel kondisi fasilitas dan menghilangkan variabel pengaruh sosial dan penggunaan (Gambar 1). Kondisi fasilitas merupakan salah satu faktor yang mempengaruhi sikap pengguna dan sikap akan mempengaruhi kepuasan dalam memanfaatkan sistem informasi [8], sehingga secara tidak langsung kondisi fasilitas akan mempengaruhi kepuasan. Modifikasi lain yaitu menghilangkan variabel pengaruh sosial dan penggunaan. Hal ini dilakukan dengan pertimbangan bahwa objek pada penelitian ini bersifat mandatory, artinya ada suatu keharusan pengguna sistem untuk menggunakan RME. Manfaat keseluruhan dipengaruhi oleh kepuasan pemakai, tetapi tidak oleh penggunaan [4]. Variabel penggunaan tidak dapat diterapkan pada lingkungan mandatory, karena pengguna memiliki kewajiban menggunakan sistem [9]. Selain itu, pengaruh sosial tidak berpengaruh terhadap harapan kinerja [10].

Berdasarkan model penelitian, maka disusunlah hipotesis sebagaimana terdapat pada Tabel 2 . Data dianalisis dengan analisis Structural Equation Modelling Partial Least Square (SEM-PLS) menggunakan SmartPLS versi 3.2.3. PLS mampu menggambarkan variabel tak terukur langsung (variabel laten) dan diukur menggunakan indikator. PLS digunakan karena data tidak didasarkan pada asumsi, tidak harus berdistribusi normal, dan jumlah sampel tidak harus besar. PLS juga banyak digunakan untuk penelitian sistem informasi yang bertujuan untuk menyelidiki adopsi teknologi [11].

\section{Hasil dan Analisis}

Analisis data kuantitatif dilakukan berdasarkan data kuesioner yang diterima dari 100 responden. Sebagian besar responden adalah perempuan (72\%), profesi perawat $(62 \%)$, latar belakang pendidikan S1 (44\%), dan masa kerja $>3$ tahun (54\%). Analisis PLS terdiri dari dua tahap, yaitu outer model 
(model pengukuran) dan inner model (model struktural).

\section{Model Pengukuran}

Pengujian yang dilakukan meliputi pengujian validitas (validitas konvergen dan validitas diskriminan) dan pengujian reliabilitas.

\section{Validitas konvergen}

Untuk exploratory research, nilai loading factor harus memiliki nilai $>0,6$ [11]. Loading factor merupakan besar korelasi antar indikator dengan variabel latennya. Pada Tabel 3 dapat dilihat hasil dari nilai loading factor untuk setiap indikator yang dimiliki masing-masing variabel laten. Indikator KI_2, KF_3, dan KF_5 tidak valid karena memiliki nilai $<\overline{0}, 6$. Untuk item yang tidak valid dilakukan penghapusan item \& tidak digunakan.

Selain itu, validitas konvergen juga melihat nilai AVE (average variance extracted) dengan nilai $>0,5$ [11]. Tabel 4 menunjukkan nilai AVE variabel penelitian.

\section{Validitas Diskriminan}

Tabel 5 menunjukkan nilai akar kuadrat AVE variabel lebih besar daripada nilai yang lain (ditunjukkan dengan angka yang dicetak tebal pada garis diagonal). Pengujian validitas diskriminan ini menandakan bahwa seluruh variabel memiliki discriminant validity yang tinggi.

\section{Composite Reliability}

Reliabilitas diukur dengan melihat nilai Composite Reliability atau Cronbachs Alpha. Nilai composite reliability harus $>0,7$ meskipun nilai 0,6 masih dapat diterima pada studi yang bersifat eksplorasi [11]. Nilai uji reliabilitas dapat dilihat pada Tabel 6 .

TABEL 1

KARAKTERISTIK RESPONDEN PENELITIAN

\begin{tabular}{lll}
\hline Karakteristik & Responden & Persentase (\%) \\
\hline Jenis & Laki-laki & $18 \%$ \\
Kelamin & Perempuan & $72 \%$ \\
Profesi & Dokter & $22 \%$ \\
& Perawat & $62 \%$ \\
& Rekam Medis & $8 \%$ \\
& Laboran & $3 \%$ \\
& Radiolog & $3 \%$ \\
& Apoteker & $2 \%$ \\
Pendidikan & Diploma & $44 \%$ \\
& S1 & $45 \%$ \\
& S2 & $10 \%$ \\
Masa Kerja & S3 tahun & $1 \%$ \\
& 2 tahun & $21 \%$ \\
& 3 tahun & $19 \%$ \\
& $>3$ tahun & $6 \%$ \\
& & $54 \%$ \\
\hline
\end{tabular}

\section{Model Struktural}

Inner model (model struktural) merupakan pola hubungan antar variabel penelitian. Evaluasi terhadap model struktural dengan melihat koefisien antar variabel dan nilai koefisien determinasi $R$ square $\left(R^{2}\right.$. Nilai $R^{2}$ dibagi menjadi 3 klasifikasi yaitu kuat $(0,67)$, moderat $(0,33)$, dan lemah $(0,19)[11]$. Nilai $R$ square $\left(\mathrm{R}^{2}\right)$ dapat dilihat pada Tabel 7.

Berdasarkan Tabel 7 dapat diinterpretasikan bahwa variabel yang tidak memiliki $\mathrm{R}^{2}$ adalah variabel independent atau variabel yang tidak dipengaruhi variabel lain. Sementara itu, variabel kepuasan informasi mempunyai nilai $\mathrm{R}^{2}$ sebesar 0,394 sehingga dapat diinterpretasikan bahwa variabel kepuasan informasi dapat dijelaskan oleh variabel kualitas informasi sebesar 39,4\% sedangkan sisanya, yakni sebesar $60,6 \%$ dijelaskan oleh variabel lain yang tidak termasuk dalam model ini. Dengan nilai $\mathrm{R}^{2}$ sebesar $39,4 \%$ maka model ini termasuk kategori model yang moderat.

Variabel harapan kinerja mempunyai nilai $\mathrm{R}^{2}$ sebesar 0,292 sehingga dapat diinterpretasikan bahwa variabel harapan kinerja dapat dijelaskan oleh variabel kepuasan informasi sebesar $29,2 \%$ sedangkan sisanya yakni sebesar 70,8\% dijelaskan oleh variabel lain yang tidak termasuk dalam model ini. Dengan nilai $\mathrm{R}^{2}$ sebesar 29,2\% maka model ini termasuk kategori model yang lemah.

Variabel kepuasan keseluruhan mempunyai nilai $\mathrm{R}^{2}$ sebesar 0,602 sehingga dapat diinterpretasikan bahwa variabel kepuasan keseluruhan dapat dijelaskan oleh variabel sikap sebesar 60,2\% sedangkan sisanya yakni sebesar 39,8\% dijelaskan oleh variabel lain yang tidak termasuk dalam model ini. Dengan nilai $\mathrm{R}^{2}$ sebesar $60,2 \%$ maka model ini termasuk kategori model yang moderat.

Variabel manfaat keseluruhan mempunyai nilai $\mathrm{R}^{2}$ sebesar 0,444 sehingga dapat diinterpretasikan bahwa variabel manfaat keseluruhan dapat dijelaskan oleh variabel kepuasan keseluruhan sebesar 44,4\% sedangkan sisanya yakni sebesar 55,6\%

TABEL 2

HIPOTESIS PENELITIAN

\begin{tabular}{cl}
\multicolumn{4}{c}{ HIPOTESIS PENELITIAN } \\
\hline H1 & $\begin{array}{l}\text { Kualitas informasi berpengaruh positif terhadap } \\
\text { kepuasan informasi }\end{array}$ \\
H2 & $\begin{array}{l}\text { Kepuasan informasi berpengaruh positif } \\
\text { terhadap harapan kinerja }\end{array}$ \\
H3 & $\begin{array}{l}\text { Harapan kinerja berpengaruh positif terhadap } \\
\text { sikap }\end{array}$ \\
H4 & $\begin{array}{l}\text { Kondisi fasilitas berpengaruh positif terhadap } \\
\text { sikap }\end{array}$ \\
H5 & $\begin{array}{l}\text { Sikap berpengaruh positif terhadap kepuasan } \\
\text { keseluruhan } \\
\text { Kepuasan keseluruhan berpengaruh positif } \\
\text { terhadap manfaat keseluruhan }\end{array}$ \\
\hline
\end{tabular}


TABEL 3

\begin{tabular}{|c|c|c|}
\hline Variabel & Indikator & Loading Factor \\
\hline Kualitas & KI_1 & 0,820 \\
\hline \multirow[t]{3}{*}{ Informasi } & KI 2 & 0,554 \\
\hline & KI_3 & 0,849 \\
\hline & KI_4 & 0,798 \\
\hline Kepuasan & KEP_1 & 0,963 \\
\hline Informasi & KEP_2 & 0,975 \\
\hline Harapan & $\mathrm{HK}_{-} \overline{1}$ & 0,830 \\
\hline \multirow[t]{3}{*}{ Kinerja } & HK_2 & 0,870 \\
\hline & $\mathrm{HK} \_3$ & 0,909 \\
\hline & $\mathrm{HK}_{-} 4$ & 0,919 \\
\hline \multirow[t]{5}{*}{ Sikap } & $\mathrm{S}_{-}{ }^{-}$ & 0,695 \\
\hline & S_2 & 0,850 \\
\hline & S_3 & 0,804 \\
\hline & $\mathrm{S}_{-}^{-} 4$ & 0,770 \\
\hline & $\mathrm{S}_{-}^{-} 5$ & 0,778 \\
\hline Kondisi & $\mathrm{KF}_{-} 1$ & 0,720 \\
\hline \multirow[t]{4}{*}{ Fasilitas } & $\mathrm{KF}_{-} 2$ & 0,760 \\
\hline & $\mathrm{KF} \_3$ & 0,477 \\
\hline & $\mathrm{KF}_{-}^{-} 4$ & 0,826 \\
\hline & KF_5 & 0,580 \\
\hline Kepuasan & KK_1 & 0,889 \\
\hline \multirow[t]{3}{*}{ Keseluruhan } & $\mathrm{KK}_{-}{ }_{2} 2$ & 0,895 \\
\hline & KK_3 & 0,835 \\
\hline & $\mathrm{KK}_{-} 4$ & 0,911 \\
\hline Manfaat & MK_1 & 0,723 \\
\hline \multirow[t]{8}{*}{ Keseluruhan } & MK_2 & 0,775 \\
\hline & MK_3 & 0,776 \\
\hline & $\mathrm{MK}_{-}^{-} 4$ & 0,789 \\
\hline & MK_5 & 0,887 \\
\hline & MK_6 & 0,854 \\
\hline & MK_7 & 0,737 \\
\hline & MK_8 & 0,680 \\
\hline & MK 9 & 0,615 \\
\hline
\end{tabular}

dijelaskan oleh variabel lain yang tidak termasuk dalam model ini. Dengan nilai $\mathrm{R}^{2}$ sebesar 44,4\% maka model ini termasuk kategori model yang moderat.

Variabel sikap mempunyai nilai $\mathrm{R}^{2}$ sebesar 0,655 sehingga dapat diinterpretasikan bahwa variabel sikap dapat dijelaskan oleh variabel kondisi fasilitas dan harapan kinerja sebesar $65,5 \%$ sedangkan sisanya yakni sebesar $34,5 \%$ dijelaskan oleh variabel lain yang tidak termasuk dalam model ini. Dengan nilai $\mathrm{R}^{2}$ sebesar $65,5 \%$ maka model ini termasuk kategori model yang moderat.

Evaluasi model juga dilihat dari nilai Goodness of Fit (GoF). Nilai GoF dihitung dengan persamaan(1). Pada SmartPLS 3.2.3 nilai communalities tidak muncul, sehingga alternatifnya menggunakan nilai rata-rata AVE.

$$
G o f=\sqrt{\overline{\mathrm{Com}} \times \overline{R^{2}}}
$$

$\overline{\mathrm{Com}}$ merupakan rata-rata communalities dan $\overline{R^{2}}$ merupakan rata-rata $\mathrm{R}^{2}$, sehingga

$$
G o f=\sqrt{0,6991 \times 0,4774}=0,5777
$$

\begin{tabular}{lc}
\multicolumn{2}{c}{ TABEL 4 } \\
NILAI AVE \\
\hline Variabel & AVE \\
\hline Kualitas Informasi & 0,584 \\
Kepuasan Informasi & 0,939 \\
Harapan Kinerja & 0,789 \\
Sikap & 0,630 \\
Kondisi Fasilitas & 0,533 \\
Kepuasan Keseluruhan & 0,780 \\
Manfaat Keseluruhan & 0,582 \\
\hline
\end{tabular}

\begin{tabular}{|c|c|c|c|c|c|c|c|}
\hline & KEP & $\mathrm{KI}$ & HK & KK & KF & MK & $\mathrm{S}$ \\
\hline KEP & 0.97 & & & & & & \\
\hline $\mathrm{KI}$ & 0.64 & 0.83 & & & & & \\
\hline HK & 0.54 & 0.61 & 0.89 & & & & \\
\hline KK & 0.75 & 0.63 & 0.68 & 0.88 & & & \\
\hline $\mathrm{KF}$ & 0.32 & 0.50 & 0.67 & 0.51 & 0.80 & & \\
\hline MK & 0.46 & 0.46 & 0.65 & 0.67 & 0.59 & 0.76 & \\
\hline $\mathrm{S}$ & 0.61 & 0.53 & 0.79 & 0.78 & 0.67 & 0.77 & 0.79 \\
\hline
\end{tabular}

TABEL 5

Keterangan: $\mathrm{KEP}=$ Kepuasan Informasi, $\mathrm{KI}=$ Kualitas Informasi, HK= Harapan Kinerja, KK= Kepuasan Keseluruhan, $\mathrm{KF}=$ Kondisi Fasilitas, $\mathrm{MK}=$ Manfaat Keseluruhan, $\mathrm{S}=$ Sikap.

Nilai GoF dikategorikan menjadi tiga, yaitu kecil $(0,1)$, menengah $(0,25)$, dan besar $(0,36)$ [11]. Dengan nilai GoF sebesar 0,5777 maka model dikategorikan sebagai GoF besar, sehingga dapat disimpulkan model penelitian ini secara substansial merepresentasikan hasil.

\section{Pengujian Hipotesis}

Pengujian hipotesis dilakukan dengan metode $\mathrm{Bo}$ otstrapping. Data dianalisis dengan tingkat signifikansi $(\alpha)=5 \%$ dan tingkat kepercayaan 95\%. Nilai $\mathrm{T}$ tabel dengan tingkat signifikansi 0,05 dan derajat kebebasan $(\mathrm{df})=(\mathrm{n}-1)=(100-1)=99$ untuk hipotesis satu ekor (one-tailed) adalah 1,66. Apabila nilai $\mathrm{T}$ statistik $>$ nilai $\mathrm{T}$ tabel, maka pengaruh antara satu variabel dengan variabel yang lain signifikan dan berlaku sebaliknya. Selain dengan melihat nilai $\mathrm{T}$, dapat juga dengan melihat $\mathrm{P}$ value. Apabila $P$ value $\leq$ nilai $\alpha=0,05$ maka pengaruh antara satu variabel dengan variabel yang lain signifikan dan berlaku sebaliknya.

Hasil pengujian hipotesis ditunjukkan pada Tabel 8. Nilai T statistik $>$ T tabel $(4,934>1,66)$ atau nilai $\mathrm{P}$ value $\leq \alpha(0,000 \leq 0,05)$, menunjukkan kualitas informasi berpengaruh positif terhadap kepuasan informasi. Nilai koefisien jalur bernilai positif 0,639 yang berarti semakin tinggi kualitas informasi, maka kepuasan informasi akan semakin tinggi. Jika informasi yang dihasilkan dari suatu sistem informasi berkualitas, maka akan meningkatkan kepuasan pengguna terhadap informasi tersebut [4]. Informasi yang dihasilkan oleh RME membantu pengguna dalam melaksanakan pekerjaan sehari-hari. Namun, pengguna merasa informasi belum disajikan dalam format yang tepat. Laporan 
TABEL 6

\begin{tabular}{llc}
\multicolumn{1}{c}{ NILAI COMPOSITE RELIABILITY \& CRONBACHS ALPHA } \\
\hline \multicolumn{1}{c}{ Variabel } & $\begin{array}{c}\text { Composite } \\
\text { Reliability }\end{array}$ & $\begin{array}{c}\text { Cronbachs } \\
\text { Alpha }\end{array}$ \\
\hline Kualitas Informasi & 0,846 & 0,761 \\
Kepuasan Informasi & 0,968 & 0,935 \\
Harapan Kinerja & 0,937 & 0,910 \\
Sikap & 0,907 & 0,881 \\
Kondisi Fasilitas & 0,816 & 0,707 \\
Kepuasan Keseluruhan & 0,934 & 0,906 \\
Manfaat Keseluruhan & 0,934 & 0,906
\end{tabular}

yang dihasilkan RME belum sesuai dengan format dari Kementerian Kesehatan, sehingga perlu dibuat penyesuaian laporan secara manual. Salah satu kriteria RME yang baik adalah menghasilkan format laporan yang dibutuhkan penggunanya [12].

Nilai T statistik $>$ T tabel $(5,144>1,66)$ atau nilai $\mathrm{P}$ value $\leq \alpha(0,000 \leq 0,05)$, menunjukkan kepuasan informasi berpengaruh positif terhadap harapan kinerja. Nilai koefisien jalur bernilai positif 0,540 berarti semakin tinggi kepuasan informasi, maka harapan kinerja akan semakin tinggi. Jika informasi yang dihasilkan berkualitas, maka akan meningkatkan kepuasan pengguna terhadap informasi tersebut. Semakin tinggi kepuasan informasi, maka secara langsung harapan kinerja pengguna terhadap sistem akan semakin tinggi [10]. Informasi yang dihasilkan oleh RME dapat dianalisis sesuai dengan kebutuhan penggunanya. Informasi tersebut membantu mempermudah dan mempercepat pekerjaan, serta meningkatkan produktivitas.

Nilai $\mathrm{T}$ statistik $>\mathrm{T}$ tabel $(5,911>1,66)$ atau nilai $\mathrm{P}$ value $\leq \alpha(0,000 \leq 0,05)$, menunjukkan harapan kinerja berpengaruh positif terhadap sikap. Nilai koefisien jalur bernilai positif 0,618 menunjukkan bahwa semakin tinggi harapan kinerja, maka sikap akan semakin baik. Harapan kinerja merupakan faktor yang membentuk sikap positif terhadap sistem informasi [4]. Responden yakin dengan menggunakan RME akan meningkatkan kinerja. Hal tersebut akan membentuk sikap positif pengguna terhadap RME. Selain itu, kemudahan yang ditawarkan RME akan memunculkan sikap positif terhadap RME. Sikap positif akan memberikan afirmasi positif, sehingga membuat pengguna akan menggunakan RME pada setiap pelayanan yang diberikan kepada pasien. Sikap tersebut didasari keyakinan bahwa RME membantu meningkatkan kinerja pengguna.

Nilai T statistik $>\mathrm{T}$ tabel $(1,948>1,66)$ atau nilai $\mathrm{P}$ value $\leq \alpha(0,027 \leq 0,05)$, menunjukkan kondisi fasilitas berpengaruh positif terhadap sikap. Nilai koefisien parameter jalur bernilai positif 0,252 berarti semakin baik kondisi fasilitas, maka sikap akan semakin baik. Sikap merupakan faktor penentu dalam implementasi sistem informasi yang bersifat mandatory [10]. Perilaku pengguna tersebut dipengaruhi keyakinan bahwa fasilitas pen-
TABEL 7

NiLAi $R$-SQUARE $\left(\mathrm{R}^{2}\right)$ VARIABEl PENELITIAN

\begin{tabular}{ll}
\multicolumn{1}{c}{ NILAI R-SQUARE $\left(\mathrm{R}^{2}\right)$ VARIABEL PENELITIAN } \\
\hline Variabel & $\begin{array}{l}\text { R square } \\
\left(\mathrm{R}^{2}\right)\end{array}$ \\
\hline Kepuasan Informasi & 0.394 \\
Kualitas Informasi & - \\
Harapan Kinerja & 0.292 \\
Kepuasan Keseluruhan & 0.602 \\
Kondisi Fasilitas & - \\
Manfaat Keseluruhan & 0.444 \\
Sikap & 0.655 \\
\hline
\end{tabular}

dukung baik fisik maupun teknis tersedia untuk mendukung sistem. Fasilitas pendukung merupakan faktor kunci keberhasilan implementasi sistem informasi kesehatan [13]. Fasilitas pendukung berupa sarana dan prasarana seperti hardware, software, dan jaringan di setiap bangsal, klinik, maupun instalasi penunjang sudah memadai. Fasilitas pendukung nonteknis seperti buku pedoman dan bantuan Staf IT dapat dengan mudah diakses. Namun, pengguna merasa fasilitas training masih kurang. Training pegawai baru dilakukan oleh pegawai lama, bukan oleh staf IT. Hal tersebut dapat menimbulkan kesalahan persepsi apabila pegawai lama tidak dapat menjelaskan secara detail. Training dapat dilakukan untuk pegawai lama untuk meningkatkan pengetahuan terkait dengan pengembangan RME yang telah dilakukan. Training akan meningkatkan pemahaman karena kurangnya pengetahuan, pengalaman, dan kesadaran penggunaan RME [14].

Nilai T statistik $>$ T tabel $(16,353>1,66)$ atau nilai $\mathrm{P}$ value $\leq \alpha(0,000 \leq 0,05)$, menunjukkan sikap berpengaruh positif terhadap kepuasan keseluruhan. Nilai koefisien jalur bernilai positif 0,776 berarti semakin baik sikap, maka kepuasan keseluruhan akan semakin tinggi. Sikap merupakan faktor yang berpengaruh dalam mengimplementasikan suatu teknologi yang bersifat mandatory [10]. Sikap positif pada pengguna sistem memunculkan kepuasan yang tinggi terhadap sistem secara keseluruhan [4]. Kepuasan merupakan respon yang muncul setelah pengguna menggunakan RME. Sikap positif pengguna terhadap RME membuat responden puas dan merasa nyaman menggunakan RME untuk menyelesaikan pekerjaannya. Untuk melihat kesuksesan sistem informasi pada lingkungan $m a-$ ndatory pengukuran yang tepat adalah kepuasan pengguna [9]. Pada lingkungan mandatory, pengguna diwajibkan menggunakan sistem sehingga intensitas penggunaan tidak berpengaruh terhadap kesuksesan implementasi.

Nilai T statistik $>\mathrm{T}$ tabel $(11,092>1,66)$ atau nilai $\mathrm{P}$ value $\leq \alpha(0,000 \leq 0,05)$, menunjukkan kepuasan keseluruhan berpengaruh positif terhadap manfaat keseluruhan. Nilai koefisien parameter jalur bernilai positif 0,666 berarti semakin tinggi kepuasan keseluruhan, maka manfaat keseluruhan 
TABEL 8

HASIL Uji HiPOTESIS Model PENELITIAN

\begin{tabular}{llllllc}
\hline $\begin{array}{l}\text { Hipo- } \\
\text { tesis }\end{array}$ & \multicolumn{1}{c}{ Jalur } & \multicolumn{1}{c}{ Ke } & \multicolumn{1}{c}{$\begin{array}{c}\text { Koefisien } \\
\text { Parameter Jalur }\end{array}$} & T Statistik & P value & Kesimpulan \\
\cline { 2 - 5 } H1 & Kualitas informasi & $\begin{array}{l}\text { Kepuasan } \\
\text { informasi }\end{array}$ & 0,639 & 4,934 & 0,000 & Hipotesis diterima \\
& & & & & \\
H2 & Kepuasan informasi & Harapan kinerja & 0,540 & 5,144 & 0,000 & Hipotesis diterima \\
H3 & Harapan kinerja & Sikap & 0,618 & 5,911 & 0,000 & Hipotesis diterima \\
H4 & Kondisi fasilitas & Sikap & 0,252 & 1,948 & 0,027 & Hipotesis diterima \\
H5 & Sikap & $\begin{array}{l}\text { Kepuasan } \\
\text { keseluruhan }\end{array}$ & 0,776 & 16,353 & 0,000 & Hipotesis diterima \\
H6 & Kepuasan keseluruhan & $\begin{array}{l}\text { Manfaat } \\
\text { Keseluruhan }\end{array}$ & 0,666 & 11,092 & 0,000 & Hipotesis diterima \\
& & & & & \\
\hline
\end{tabular}

akan semakin baik. Variabel kepuasan merupakan faktor determinan terhadap manfaat yang dirasakan pengguna [6]. Secara langsung kepuasan responden mempengaruhi manfaat yang diperoleh dari penggunaan RME. Semakin tinggi kepuasan pengguna, maka pengguna akan semakin banyak mengeksplorasi RME untuk mendapatkan manfaat yang lebih banyak. Pengguna RME merasa puas dan yakin menggunakan RME dapat meningkatkan manfaat RME dalam pekerjaan mereka. Pengguna lebih memahami manfaat dan dampak RME terhadap pekerjaan ketika manfaat tersebut dapat dirasakan secara langsung [15]. Pengguna merasa puas dan yakin menggunakan RME dapat meningkatkan manfaat RME untuk pekerjaan mereka. Hal ini dibuktikan dengan manfaat yang dirasakan responden, yaitu kemudahan dan kecepatan akses, kemudahan komunikasi, dan efisiensi pelayanan.

\section{Kesimpulan}

Seluruh variabel MMUST berpengaruh positif terhadap kesuksesan implementasi RME. Kualitas informasi berpengaruh positif terhadap kepuasan informasi. Kepuasan informasi berpengaruh positif terhadap harapan kinerja. Harapan kinerja dan kondisi fasilitas berpengaruh positif terhadap sikap. Sikap berpengaruh positif terhadap kepuasan keseluruhan. Kepuasan keseluruhan berpengaruh positif terhadap manfaat keseluruhan. Untuk pengembangan RME lebih lanjut, maka output laporan yang dihasilkan RME perlu disesuaikan dengan format dari Kementerian Kesehatan. Selain itu, staf IT juga perlu memberikan training untuk pegawai baru.

\section{Referensi}

[1] B. N. M. Bilimoria, "Electronic health records implementation: what hospitals and physicians need to know to comply with recent health law requirements," Bloomberg Corporate Law Journal, vol. 501, pp. 415-425, 2007.

[2] J. D. Hatton, T. M. Schmidt, and J. Jelen, “Adoption of electronic health care records: phy- sician heuristics and hesitancy," Procedia Technology, vol. 5, pp. 706-715, 2012.

[3] N. Shaw, "The role of the professional association: a grounded theory study of electronic medical records usage in ontario, canada," International Journal of Information Management, vol. 34, no. 2, pp. 200-209, 2014.

[4] C. E. Koh, et al., "A model for mandatory use of software technologies: an integrative approach by applying multiple levels of abstraction of informing science," Informing Science: The International Journal of an Emerging Transdiscipline, vol. 13, 2010.

[5] Morris, M. G., et al., "User acceptance of information technology: toward a unified view," MIS Quarterly, vol. 27, no. 3, pp. 425-478, 2003.

[6] W. H. DeLone and E. R. McLean, "DeLone and McLean model of information systems success: a ten-year update," Journal of Management Information Systems, vol. 19, no. 4, pp. 9-30, 2003.

[7] B. H. Wixom and P. A. Todd, "A theoretical integration of user satisfaction and technology acceptance," Information System Research, vol. 16, 2005.

[8] Bergersen, B.M., "User satisfaction and influencing issues," Network and System Administration Research Surveys, vol. 1, pp.5-26, 2004.

[9] P. Rawstorne, et al., "An integrative model of information systems use in mandatory environments," ICIS 1998 Proceeding, pp. Paper 32, 1998.

[10] I. Mitropoulos, "Management information systems in health sector: evidence of mandatory use," INFOCOMP, pp. 51-53, 2015.

[11] I. Ghozali and H. Latan, Partial Least Squares: Konsep, Teknik, dan Aplikasi Mengguna- 
kan Program SmartPLS 3.0. Semarang: Badan Penerbit Universitas Diponegoro, 2015.

[12] É. Maillet, et al., "Modeling factors explaining the acceptance, actual use, and satisfaction of nurses using an electronic patient record in acute care settings: an extension of the UTAUT," International Journal of Medical Informatics, vol. 84, no. 1, pp. 36-47, 2014.

[13] M. Khalifa, "Barriers to Health Information Systems and Electronic Medical Records Implementation A Field Study of Saudi Arabian
Hospitals," Procedia Computer Science, vol. 21, pp. 335-342, 2013.

[14] G. Arias, et al., "The 7 key factors to get successful results in the it development projects," Procedia Technology., vol. 5, pp. 199-207, 2012.

[15] M. P. Gagnon, et al., "Electronic health record acceptance by physicians: testing an integrated theoretical model," Journal of Biomedical Informatics, vol. 48, pp. 17-27, 2014. 